\title{
NURSING WORK IN AN INDIGENOUS SUPPORT INSTITUTION ${ }^{1}$
}

\author{
Aridiane Alves Ribeiro², Cinira Magali Fortuna³, Cássia Irene Spinelli Arantes ${ }^{4}$
}

${ }^{1}$ This article presents results from the dissertation - Concepções de trabalhadores de enfermagem sobre o processo de cuidar em uma
instituição de apoio ao indígena, developed at the Nursing Graduate Program of the Universidade Federal de São Carlos (UFSCar),
in 2012 .
${ }^{2}$ Doctoral student in the Interunit Doctoral Program in Nursing, Escola de Enfermagem de Ribeirão Preto (EERP)of the Universidade
de São Paulo (USP). Ribeirão Preto, São Paulo, Brazil. E-mail: aridianeribeiro@gmail.com
${ }^{3}$ Ph. D. in Nursing. Professor at the Maternal-Infant and Public Health Department of USP/EERP. Ribeirão Preto, São Paulo,
Brazil. E-mail: fortuna@eerp.usp.br
${ }^{4}$ Ph. D. in Nursing. Professor at the Nursing Department of UFSCar. São Carlos, São Paulo, Brazil. E-mail: arantes@ufscar.br

ABSTRACT: This descriptive and qualitative study aimed to analyze the process of nursing work in an institution of Indigenous health attention. The investigation was developed at Support House to Indians in Mato Grosso do Sul State, Brazil. During the data collection step, observation of the process of working was performed; as well field journal was used in order to register the observations. Also, semi structured interviews were done with ten nursing workers. The data were analyzed using thematic content analysis from the theoretical perspective of work process in health care. We identified two thematic categories: relational tools needed in the care of the Indigenous people; schedule and registration as the central element of the production process of care. The workers reported the importance to use the soft technology to take care. However, there are elements of process of work, as scheduling, institutional norms, and the logic of biomedical model which interpose into the care.

DESCRIPTORS: Nursing care. Work. Health of indigenous peoples.

\section{O TRABALHO DE ENFERMAGEM EM UMA INSTITUIÇÃO DE APOIO AO INDÍGENA}

RESUMO: Trata-se de estudo descritivo, de abordagem qualitativa, cujo objetivo foi analisar o processo de trabalho da enfermagem em uma instituição indígena. O cenário estudado foi uma Casa de Apoio à Saúde do Índio de Mato Grosso do Sul, Brasil. Realizouse observação do processo de trabalho, registradas em diário de campo e entrevistas semiestruturadas com dez trabalhadores de enfermagem. Para análise dos dados, utilizou-se análise de conteúdo temática, na perspectiva teórica do processo de trabalho em saúde. Identificaram-se duas categorias temáticas: ferramentas relacionais necessárias no processo de cuidar do indígena; agendamento e registro como elementos centrais do processo de produção do cuidado. Os trabalhadores relataram a importância das tecnologias leves para o cuidado. Entretanto, no processo de trabalho há elementos como agendamento, normas institucionais e a lógica biomédica interpõe-se ao cuidado.

DESCRITORES: Cuidados de enfermagem. Trabalho. Saúde de populações indígenas.

\section{EL TRABAJO DE ENFERMERÍA EN UNA INSTITUCIÓN PARA APOYAR INDÍGENA}

RESUMEN: Este estudio descriptivo y cualitativo objetivó analizar el proceso de trabajo de enfermería de una institución de atención a la salud indígena. La investigación se desarrolló en una Casa de Apoyo de Salud Indígena del Estado de Mato Grosso do Sul, Brasil. Se utilizaron la observación, diario de campo y entrevistas semiestructuradas como técnicas de recolección de los datos. Participaron diez trabajadores. Se utilizó análisis de contenido para analizar los datos desde la perspectiva teórica del proceso de trabajo en salud. El marco teórico para el análisis fue el proceso de trabajo en salud en su micro-política, resultando en dos categorías: herramientas relacionales necesarias en el proceso de cuidar del indígena; "programación" y registro como elemento central del proceso de producción del cuidado. Los trabajadores informaron la necesidad de utilizar tecnologías ligeras para el cuidado. Sin embargo, existen elementos de trabajo, como programación, normas institucionales y la lógica del modelo biomédico se interpone al cuidado.

DESCRIPTORES: Atención de enfermería. Trabajo. Salud de poblaciones indígenas. 


\section{INTRODUCTION}

In the provision of care services to Indigenous people, nursing workers constantly face different conceptions than those usually found in traditional western care models. ${ }^{1}$ The Indigenous society has its own health care system, based on practices and rituals that are directly related to nature and religion, from a mindset that values immaterial, human, and natural forces. ${ }^{1}$ Despite having their own healthcare system, Brazilian Indigenous also use health care services provided by the Unified Health System (SUS).

Health care services to native people require multidisciplinary knowledge of health practices, which results in an axiomatic relationship between life, human and social sciences..$^{2-3}$

Nursing is one of these subjects, which has being considered in this paper/study as a social practice that is built historically and socially through the organization of work and society in a broader manner. ${ }^{4}$ From this point of view, nursing field is neither the result of individual practices of their members nor of the decision of class entities. It is the result of changes in contemporary work in the current society, which is part of a capitalist method of production that has contradictions between use and exchange values.

In the care of Indigenous people, to consider nursing work as a social practice ${ }^{4}$ is to understand its dynamics and its method of production. There is not a unique nursing model, but several. Nursing is not static, it changes, it adapts, and it transforms and reproduces itself.

Considering that the biomedical model still prevails in healthcare services, and in order to ensure equal and fair care of Indigenous people, the National Policy of Health Care of Indigenous People calls for a special health care service. It refers to the respect and integration of the traditional Indigenous medicine and its cultural particularities with health services provided to Indigenous people. ${ }^{1,5}$

This recommendation has not been effective, since health professionals, especially nursing workers, are not prepared to work with Indigenous people and to perceive, understand and accept their traditional therapeutic practices and conceptions. ${ }^{6}$

The singularity of this intercultural encounter, which is inherent to nursing care provided to native people, makes it a relevant object of theoretical study. However, there are not many studies published on the matter. After a survey on available data, it was found that there is a lack of information in the Brazilian literature about nursing work with Indigenous people. Considering that the legal basis that supports health care of Indigenous people was implemented in the 1990's, the production of knowledge on the matter is necessary and urgent.

Thus, driven by the theoretical framework of work processes, we aimed to understand how nursing care is provided to Indigenous people in health care services. In order to do this, the following question was asked: does working with people with special characteristics, such as Indigenous people, result in particular nursing work processes?

Based on this question and after a review of the literature, the aim of the present study was to analyze the nursing work process in an Indigenous health care center. The study was carried out in an institution located in the Mato Grosso do Sul State, and its focus was mainly on the instruments of the work process.

\section{THEORETICAL-METHODOLOGICAL APPROACH}

The analysis of nursing care is founded on the theoretical approach of the work process in health. ${ }^{7}$ From this point of view, the provision of healthcare services is a live labor, which takes place in interceding relationships, being a setting of interactions between subjective individuals who are part of the health work micropolitics. ${ }^{8}$

In modern societies, structured knowledge of each field and increasingly modern technologies are associated with the specialization of professional performance ${ }^{9}$ and may convert healthcare services into mere procedures. ${ }^{8-10}$

In the process of care, which is focused on the patient, it is important to understand the cultural differences, both health and disease as a sociocultural process and the experiences of the subjects involved. ${ }^{1-4}$ These elements are relevant to Indigenous health care. In order to share the care process, it is important to understand the way of life of the person being cared of, and to take it into account. In this sense, the historicaldialectic approach is relevant to understand 
the work process within a health care center for Indigenous people.

Nursing work is developed by means of interaction and integration with other categories of workers, thus it is not possible to talk about it without considering health care work and its general characteristics. Hence, health care work ${ }^{7}$ is immaterial, that is, it does not produce a concrete good, it deals with a social right, which is the right to have access to good quality health services, being consumed at the same moment as it is produced. ${ }^{8}$

In order to understand the work process in health and nursing field, some elements are highlighted as object of work, that is, what workers will be devoted to. In the case of health, the object of work can be the sick body, symptoms or even the human being as a whole, with their needs and values. ${ }^{7}$

The instruments of the work process are knowledge and all the tools that are used to achieve a goal. This process meets the needs, but it also creates them. The object of work, the instruments, the needs and the goal to be achieved may not be clear for workers.?

The set of work processes, within different health services, meets the needs of care models and is defined by them. Therefore, the nursing work at the Indigenous Support Center (Casai, as per its acronym in Portuguese) can be analyzed by means of the instruments used in the work process.

This is a descriptive case study with a qualitative approach. The setting studied was the Casai of the Special Indigenous Health District (DSEI, as per its acronym in Portuguese) in the state of Mato Grosso do Sul, Brazil. The Indigenous lands are divided into 36 DSEIs, according to sociodemographic, geographic and cultural factors. Within each DSEI, the healthcare service flow begins at the base pole (basic health care unit of the village), and for more complex cases, sick Indigenous people are referred to the SUS services. During treatment and/or recovery carried out outside the village, the person can rely on the Casai, where there is nursing care. ${ }^{5}$

Semi-structured interviews were conducted, with questions about work conceptions and care services provided at Casai, and the prevailing instruments in the process were identified. Field work included observation and interviews, and it took place between January and February of
2011. The individuals interviewed were ten nursing workers, namely a nurse (bachelor nurse) and nine nursing technicians (practical nurse). However, these professional categories were not distinguished in the presentation of results, in order to comply with ethical precepts.

During the two-month stay at the research field, observations were made at different work shifts and in different days of the week, from Monday to Sunday. These observations were made carefully and respecting the theoretical framework, and we sought to describe and interpret work from inside. ${ }^{11}$ The impressions were reported in a field diary and they included gesture, habits and beliefs. These observations provided the input needed to reaffirm or contrast information obtained in formal interviews. The participants were informed about the study and signed a Free and Informed Consent Form. The research proposal was approved by the Human Research Ethics Committee of the Federal University of São Carlos, under protocol number $384 / 210$.

The analysis of empirical material - statements and observations - was performed by means of the theme analysis technique. ${ }^{12}$ The methodological procedures followed in the analysis were: thorough reading, material exploration, categorization and inference. ${ }^{12}$ After the identification of the meaning cores, the results were organized in two theme categories: relational tools that are necessary to the care of Indigenous people and scheduling and records as central elements of the care process.

In the presentation of results, interviewees' speeches were represented by the letter E, followed by a number between 1 and 10, which corresponded to the order in which they occurred.

\section{RESULTS AND DISCUSSION}

In order to present the nursing work process at Casai, we will briefly explain its functioning, and then we will deal with the categories related to the main instruments used in the process.

\section{Casai as a transitory place}

The studied Casai has 35 beds, of which 32 are for adults, 2 for children and one for isolation. The monthly service flow is of 344 Indians in average, including patients who stay for days 
or weeks, those who are in transit (who normally spend a day at the institution), and those relatives who are accompanying sick people.

The team of workers at Casai is composed of a manager (coordinator), a front desk assistant, an administrative manager, three administrative assistants, ten drivers, three cooks, two general service assistants and six watchmen. As for the nursing staff, there are nine technicians and a head nurse. Nursing care is provided 24 hours, with 12-hour morning and night shifts, and the rest period is 36 hours.

With exception to the manager, the front desk assistant, two drivers and a nursing technician, who are all permanent employees, all of the other workers are outsourced and hired by nongovernmental organizations.

Nursing care is functionally and spatially divided into two sectors: scheduling and the nursing unit. In the first department, there is a nursing technician, whose role is to carry out actions such as scheduling consultations and exams and communicating with the base pole and other health services. In the second one, there are other nursing technicians whose main responsibilities include providing care to patients and accompanying them in consultations and procedures carried out in the complex organization of referral to the city's health services. The nurse works in both departments, but mainly in scheduling.

The nursing technicians of the nursing unit are on duty for 12 hours. The nurse and the scheduling technician work full time in their department, that is, eight hours a day, from Monday to Friday.

In this sense, depending on their role in the work process, nursing workers will focus either on the direct contact with patients or on the management of patients' stay. This direct work is organized according to the procedures required in the next step of health care, which in this case occurs in other services, and complies with protocols or moderate/complex or complex procedures such as surgery preparation, examinations and medication. The following excerpts illustrate this aspect:

[...] the first thing we do is to prepare the 7am medication. Then we give the medication and assess the vital signs. [...] After this dressing is done, we begin to prepare materials to do the $2 \mathrm{pm}$ and $8 \mathrm{pm}$ dressings [...] (E.2).
[...] as soon as I am on duty [...] I go check if these patients are at Casai indeed, room by room, I greet and talk to them. Then I start to do all the work as it should be done. It's giving medication. It's making reports, on sheets and on the book, just the way we do [...] (E.10).

This care is given by nursing technicians in a rotation system, which means that there is always a time interval and experiences the Indigenous people have that are not perceived by everyone, and this makes records have an important place in the work process. The management of stays is carried out by scheduling workers. Records and scheduling are topics that were studied, as were relational tools, presented as it follows.

\section{Relational tools that are necessary to the care of indigenous people}

The care provided to Indigenous people, as per interviewees, is based on two basic elements: the ability of health professionals to deal with Indigenous people and a relationship of trust. Three relational tools are necessary: empathy, affection and trust, as pointed out in the statements below:

[...] I talk [...] as soon as you earn their trust, you have it all [...] (E.10).

[...] I think that everyone has the ability to approach people and talk [...] (E.5).

Concerning empathy, we can highlight the experiential meaning of the relationship between the self and the other:

[...] I treat every patient as if they were my father or mother [...] (E.2).

there is affection [...]. And then, when I take care of them, I like to be affectionate, it helps [...] (E.3).

[...] in a conversation with one of the nursing technicians [...] she said it is necessary to understand and appreciate them, otherwise we can't help them [...] (Field diary).

This perspective refers to the social logic that was historically built by nursing, which places this work not as a social practice in which workers sell their workforce in a capitalist method of production, but rather as a vocation whose pillars are empathy, affection and trust.

Establishing bonds and having affection are certainly important and simple procedures that are considered to bring the worker closer to the patients' universe. This type of interven- 
tion favors "caring with", since it horizontalizes relationships. A bond should be established with patients, since it is an essential part of work and also there is a de jure relationship. However, establishing bonds is considered as a personal skill of the individual who, in their conception, establishes bonds because they are good and devoted professionals.

This aspect seems not to distinguish the nursing work performed at Casai from that of other health institutions, since relational tools are appreciated but also understood as a vocational and individual action.

Attention should be drawn to the fact that these are Indigenous people, who were historically subjugated by western civilizations, so there is a risk of developing relationships between nursing staff and patients that are influenced by pre-existing conceptions. However, these encounters can be fruitful for caregiving thanks to good individual actions.

In the care process at Casai, it is necessary to develop relationships based on trust. This is a characteristic element presented by researchers of indigenous relationships. ${ }^{13-15}$

Although they admit the need for relational tools in the care of Indians at Casai, some workers mentioned having difficulties in using these procedures. Very often, non-indigenous professionals are not prepared to provide care to these people ${ }^{6}$, since their health practices are based on biomedicine and have an approach that medicalizes social problems. ${ }^{14}$

In addition, interviewed workers stated they did not attend any training when they began to work at Casai, nor later. It should be noted that this mishap occurs in different Indigenous health care centers. ${ }^{1,14-15}$ Low level of training is associated with difficulties to have social and political investments, with the history of the country concerning care and social inclusion of Indigenous people, and with historical and social shaping of health policies.

The committed interceding relationship established with Indigenous person should not only be based on trust but also consider their native culture and ethnic diversity. It is important to have an institutional support to promote continuing education as a way to overcome the lack of knowledge regarding indigenous traditional medicine. ${ }^{16}$
By not prioritizing training of professionals, the institution expresses its appreciation of the biomedical model and the performance of work by means of moderate/complex or complex procedures, that is, with material equipment.

\section{Scheduling and records as central elements of the care process}

Scheduling is perceived by nursing workers as a central element of work at Casai. Statements of individuals show an appreciation of working with scheduling, since organizing activities is essential for the institution's good functioning:

[...] scheduling is essential, as it is where everything gets organized [...] (E.2).

[...] without it, it is not possible to work, it works like the brain [of Casai] [...] (E.1).

As it was observed at Casai, the work process is divided into scheduling and nursing unit. In the first, procedures are organized and planned, such as the itinerary that Indigenous patients will have to follow during their treatment and/or recovery outside their village. As for nursing unit workers, they are responsible for direct care of patients and relatives who are hospitalized.

From this point of view, scheduling is crucial at Casai. However, work goes beyond that; it includes other aspects such as care of people who wait to be served and/or for the end of their treatment, as well as care of accompanying people.

Scheduling is where decision-making takes place at Casai. It involves planning care of patients and actions of the nursing staff, as well as of the driver, the kitchen and cleaning staff.

The separation between scheduling/planning and the nursing unit segments nursing duties. In addition, scheduling is considered as:

[...] an extension of nursing that is responsible for organizing patients that will be treated by Casai [...] (E.7).

The technical and social division of work and the division between intellectual and manual work are evident here. ${ }^{17}$ The segmentation of nursing in planning/scheduling and performing/providing care characterizes this division, since the individuals involved in scheduling hardly work at direct health care to Indigenous people at the Casai.

Scheduling is more about "thinking" where- 
as the nursing unit is more about "executing", and the execution of tasks is guided by others' planning/orders. It is assumed that those who think do not act, and those who act, do it without planning.

Obviously, as far as relational space is concerned, nursing workers have some autonomy to create, even if this is not perceived, and consequently to think about care together with Indigenous people. However, goals and actions to be taken on duty make work concrete. ${ }^{8}$

It is worth mentioning that the organizational structure at Casai requires the performance of everything that has been planned for the day, which goes against the free organization of work that favors a more horizontalized distribution of authority. ${ }^{18-19}$ Thus, it is necessary to establish cross-sectional lines between antagonistic forces of autonomy and delegation of responsibilities, so as to bring out the power of these two factors. ${ }^{18}$

The prevalence of the division between planning and execution of work, and the performance by means of moderate/complex or complex procedures is not a reality particular to health services provided to Indigenous people. By contrast, procedure-centered actions are rooted in a healthcare model and are an obstacle to the implementation of values recommended by the SUS. ${ }^{8}$

Another approach to the performance of work process by means of moderate/complex procedures is the recording of work. This is another leading instrument of the nursing work at Casai. It was evident that nursing records play a key role at work. However, it is acknowledged that nursing notes are a bureaucratic activity performed to ensure a rational work process. The provision of healthcare services is particularly influenced by this aspect.

Bureaucracy was mentioned as the excessive amount of records made:

[...] the bureaucratic part [...] is necessary, it is everywhere. We have more of it here, because there are a lot of documents [...] (E1).

[...] besides writing, you still have to provide care to patients. This is the rule [...] (E8).

It is possible to conclude that workers do not acknowledge nursing records as a mechanism to guarantee the continuity of the care. They act with the purpose of complying with rules. Even care actions are perceived as norms to be followed.

The registration in many forms is a rule at Casai, as we can see in the statements below:

[...] the nursing technician seems to be very busy. There are several schedules [in this context, procedures that patients will be referred to] that have been confirmed but need to be copied out to the nursing report book (Field diary).

Such records are done manually and require the registration of sheets and diet checklists or death spreadsheets. Bearing in mind that information related to actions and observations performed must be recorded in order to manage and proceed with care, and for assessing the services provided, the manual recording must be clear and objective from a legal point of view so as to avoid possible communication failures between staff members. ${ }^{20}$ However, manual records favor the occurrence of mistakes, erasures or illegible handwriting, especially in the routine of a work process with strict rules. In addition, this type of record is considered a limited and outdated communication method compared to the different technologies currently available. ${ }^{20}$

Workers of Casai perceive nursing records as an essential element of the work process, as they provide safety in the event of any occurrence. The following statement confirms this point of view: [...] I see it more as a guarantee that everything that was made was recorded. That it is written down [...] (E.4).

Contrary to these results, another study ${ }^{7}$ indicated a negative feeling from nurses regarding administrative tasks - except for those related to control and planning of activities.

Instead of favoring complete and committed care, nursing notes at Casai have become something boring and pointless for workers, as we can see in this excerpt of the field diary: [...] I've been noticing that technicians write down nursing procedures on the report book and the clinical record. They look extremely bored [...] (Field diary).

\section{CONCLUSIONS}

In the studied setting, the nursing work process shows fragmentation and creates different spaces for those who plan and those who provide direct care, and this approach strengthens the technical and social division of work.

On the one hand, there is the presence of a 
discourse about care, which reaffirms the appreciation of the use of relational tools. On the other hand, these relational tools are based on an affective and family approach that does not necessarily consider the other as capable, with their own legitimate beliefs and values. This point of view can undervalue the provision of care services to Indigenous people as a right, which can favor the historical submission of this population to official health services.

The overvaluing of scheduling and records, presented in the statements above, show that there are hierarchical relationships in the nursing work process. Scheduling is on top, with its normative organizational structure, subordinating the activities of the nursing unit workers.

It is worth mentioning that the aspects presented in the work process of Casai are close to those found in the literature, which states that the logic of care is not centered on patients' needs.

It was not the aim of this study to fully explore the topic on the nursing work process at Casai. Among the limitations of this study, we can mention that Indigenous people who were treated at Casai during data collection did not participate in the study. In order to understand the nursing care services provided to native people, it is essential that they are properly represented in the study. Further research on care and work process at Casai is important, and it should involve Indigenous people, workers and managers.

\section{REFERENCES}

1. Langdon EJ. Cultural diversity and the challenges of Brazilian Indian health policy. Saude Soc. 2007 Mai-Ago; 16(2):7-12.

2. Boehs AE, Monticelli M, Wosny AM, Heidemann IBS, Grisotti M. The necessary interface among nursing, health education, and the concept of culture. Texto Contexto Enferm. 2007 Abr-Jun; 16(2):307-14.

3. Langdon EJ, Wiik FB. Anthropology, health and illness: an introduction to the concept of culture applied to the health sciences. Rev Latino-Am Enfermagem [online]. 2010 [acesso 2013 Jan 15]; 18(3):459-66. Disponível em: http:/ / www.scielo. $\mathrm{br} / \mathrm{pdf} / \mathrm{rlae} / \mathrm{v} 18 \mathrm{n} 3 / \mathrm{pt}$ 23.pdf

4. Sá ET, Pereira MJB, Fortuna CM, Matumoto S, Mishima SM. The work process in the reception of a Primary Care Unit: workers' view. Rev Gaúcha Enferm [online]. 2009 [acesso 2011 Set 14]; 30(3):461-7. Disponível em: http://seer.
ufrgs.br/RevistaGauchadeEnfermagem/article/ view/8690/6967

5. Fundação Nacional da Saúde (BR). Política de atenção à saúde dos povos indígenas. $2^{\mathrm{a}} \mathrm{ed}$. Brasília (DF): MS; 2002.

6. Novo MP. Politics and inter-medicality in the Upper Xingu: from model to practice in Indigenous health care. Cad Saúde Pública. 2011 Jul; 27(7):1362-70.

7. Merhy EE, Franco TB. Cartographies of Work and health care. Tempus - Actas Saúde Coletiva. 2012; 6(2):151-63.

8. Ceccin RB, Merhy EE. Intense micropolitical and pedagogical action: humanization between ties and perspectives. Interface (Botucatu). 2009; 13(Sup 1): 531-42.

9. Matos E, Pires DEP. Interdisciplinary care practices: a promising way. Texto Contexto Enferm. 2009 AbrJun; 18(2):338-46.

10. Carvalho BG, Peduzzi M, Mandú ENT, Ayres JRCM. Work and Inter-subjectivity: a theoretical reflection on its dialectics in the field of health and nursing. Rev Latino-Am Enfermagem [online]. 2012 [acesso 2012 Jan 30]; 20(1). Disponível em: http:/ / www. scielo.br/pdf/rlae/v20n1/pt_04.pdf

11. Oliveira CR. O trabalho do antropólogo: olhar, ouvir, escrever. Rev Antropol. 1996; 39(1):13-37.

12. Bardin L. Análise de conteúdo. $4^{\mathrm{a}}$ ed. Lisboa (PT): Edições 70, 2009.

13. Gonçalves LJM. Na fronteira das relações de cuidado em saúde indígena. São Paulo (SP): Annablume; 2011.

14. Fóllér M. Intermedicalidade: a zona de contato criada por povos indígenas e profissionais de saúde. Moon J, tradutor. In: Langdon EJ, Garnelo L, organizadores. Saúde dos povos indígenas: reflexões sobre antropologia participativa. Rio de Janeiro (RJ): Associação Brasileira de Antropologia; 2004. p.129-47.

15. Langdon EJ; Diehl EE. Participation and autonomy in the intercultural contexts of Indian Health: reflections from southern Brazil. Saude Soc. 2007 Mai-Ago; 16(2):19-36.

16. Held AAV, Lopes MSC, Sá MNB, Porto DOS. Perception of health among the Guarany Mbyá ethnic group and health care. Ciênc Saúde Colet [online]. 2011 [acesso 2012 Nov 01]; 16(supl.1). Disponível em: http:/ / www.scielo.br/scielo.php?script=sci_arttex t\&pid=S1413-81232011000700024

17. Peduzzi M, Schraiber LB. Processo de trabalho em saúde. In: Pereira IB, França JC, organizadores. Dicionário da educação profissional. $2^{\mathrm{a}} \mathrm{ed}$. Rio de Janeiro (RJ): EPSJV; 2008. p.320-7.

18. Campos GWS.Democratic management and new craft: concepts to rethink integration between autonomy and responsibility in health work. Ciênc Saúde Coletiva. 2010 Aug; 15(5):2337-45. 
19. Matumoto S, Mishima SM, Fortuna CM, Pereira MJB, Almeida MCP. Preparing the care relationship: a welcoming tool in health units. Rev Latino-Am Enfermagem [online]. 2009 [acesso 2011 Dez 4]; 17(6). Disponível em: http://www.scielo.br/pdf/ rlae/v17n6/pt_12.pdf
20. Santos SR, Paula AFA, Lima JP. Nurses and their perception about the manual recording system in patients' files. Rev Latino-Am Enfermagem [online]. 2003 [acesso 2012 Dez 10]; 11(1). Disponível em http://www.scielo.br/pdf/rlae/v11n1/16563.pdf 